\title{
Spray-dried Powder of Bacillus megaterium for Control of Rice Sheath Blight Disease: Formulation Protocol and Efficacy Testing in Laboratory and Greenhouse
}

\author{
A. Chumthong ${ }^{1 *}$, R. WiwattanapatapeE 2 , H. Viernstein ${ }^{3}$, \\ A. PEngnOO 4 and M. KanjanamaneEsathian ${ }^{5}$ \\ ${ }^{1}$ Department of Agricultural Technology, Faculty of Agricultural Technology, Songkhla Rajabhat University, \\ Muang, Songkhla 90000, Thailand \\ ${ }^{2}$ Department of Pharmaceutical Technology, Faculty of Pharmaceutical Sciences, \\ Prince of Songkla University, Hat Yai, Songkhla 90112, Thailand \\ ${ }^{3}$ Department of Pharmaceutical Technology and Biopharmaceutics, Faculty of Life Sciences, \\ University of Vienna, Althanstr.14, A-1090 Vienna, Austria \\ ${ }^{4}$ Department of Earth Sciences, Faculty of Natural Resources, Prince of Songkla University, HatYai, \\ Songkhla 90112, Thailand \\ ${ }^{5}$ Plant Production Technology Program, Faculty of Animal Science and Agricultural Technology, \\ Silpakorn University, Phetchaburi IT campus, Cha-Am, Phetchaburi 76120, Thailand
}

(Received 13 February 2015; Accepted 15 April 2015)

\begin{abstract}
A spray-dried powder containing Bacillus megaterium was developed and tested for control of rice sheath blight disease in the greenhouse. The formulation consisted of $20 \mathrm{ml}$ of an endospore suspension of $B$. megaterium, $20 \% \mathrm{w} / \mathrm{v}$ of skim milk powder and $1.25 \% \mathrm{w} / \mathrm{v}$ of polyvinyl pyrrolidone k-90, that were mixed and spray dried at $120{ }^{\circ} \mathrm{C}$. The powder displayed good physical characteristics, such as a low-moisture content and a high solubility in water. Bacterial viability in the powder was $3.5 \pm 0.1 \times 10^{11} \mathrm{cfu} / \mathrm{g}$ after production and remained relatively stable (at $2.2 \pm 0.1 \times 10^{10} \mathrm{cfu} / \mathrm{g}$ ) after 12 months of storage at room temperature. In the laboratory, a $0.1 \%(\mathrm{w} / \mathrm{v})$ aqueous solution of the formulation was effective in inhibiting the mycelia growth of Rhizoctonia solani ( $98.5 \pm 0.1 \%$ inhibition). Under greenhouse conditions, a $0.1 \%(\mathrm{w} / \mathrm{v})$ aqueous solution applied by either spraying 1 day before inoculating $R$. solani or spraying 1,7 and 15 days after inoculation of rice plants with $R$. solani was more effective in suppressing sheath blight disease than the blank formulation but was less effective than a chemical fungicide control.
\end{abstract}

Keywords: Bacillus megaterium, bio-pesticide, formulation, rice disease, spray-dried powder

\section{Introduction}

Rice sheath blight, caused by Rhizoctonia solani, is one of the most destructive rice diseases in Thailand, especially in the areas where rice has been cultivated continuously. In high-input and high-production environments, sheath blight disease accounts for a 6 to $10 \%$ loss annually in both temperate and tropical regions of Asia (Savary et al. 2000).

*Corresponding author; E-mail: amorn_3@yahoo.com 
Biological control with bacteria or fungi has been established as a key method to combat rice sheath blight disease (Gnanamanickam et al. 1992; Kumar et al. 2013; Naeimi et al. 2010; Mosquera-Espinosa et al. 2013). Technical difficulties in transforming a fresh culture of the selected control micro-organisms for an effective delivery to a potential disease site continues to limit the ability to effectively control plant diseases. These technical difficulties and the limited amount of research in formulation development means there are still no effective standard procedures for introducing antagonists to control sheath blight disease in the market. Rice farmers therefore have few biological options and must use chemical fungicides.

There has recently been increased research and development in producing formulations of antagonists for the control of sheath blight disease of rice (Kanjanamaneesathian et al. 2009; Kumar et al. 2013). Suspensions of control bacteria produced in bulk by normal industrial fermentation have been investigated and employed to control diseases of rice in the People's Republic of China. However the inherent characteristics of this simple product may restrict its shelf life, and requires that it be used immediately after production.

In order to prolong shelf life, increase efficacy and allow for commercialization of a formulated antagonist, it is important to keep the bacterium in a dormant state, while maintaining its viability. In the case of a Bacillus species this may simply require the formulation of a suitable preparation of viable spores.

Spray-drying can be an efficient method for transformation of aqueous suspensions of biological materials into solid materials (Conrad et al. 2000). Spray-drying has been routinely used for the preservation and concentration of microorganisms (Desmond et al. 2001). This technique has also been used for preparing starter cultures in the agricultural industry (Johnson and Etzel 1995) and for other bio-products (To and Etzel 1997a, b). The product of the spray-drying method that contained high numbers of viable microorganisms is desirable for use in various commercial applications, such as preserving food (Ananta et al. 2005), agricultural products (Horaczek and Viernstein 2004), pharmaceuticals (Boza et al. 2004; Zamora et al. 2006) and to control plant disease (Yánez-Mendizábal et al. 2012).

However, spray-drying can damage cells through heat shock and the abrupt removal of water from cells, leading to cell shrinkage and desiccation. To reduce or prevent these adverse effects, protective agents such as skim milk and polyvinyl pyrrolidone (PVP) have been investigated for their potential to maintain the viability of the microorganisms during spray drying (Abadias et al. 2001; Bühler 2001).

Skim milk powder has been reported to preserve cell viability by protecting cells from the abrupt loss of free water and changes in temperature during storage (Burges 1998; Selmer-Olsen et al. 1999). PVP is also a useful formulation excipient, as it is a binding powder, can form films, acts as an excellent bulking agent and increases the viscosity (Bühler 2001).

In this study, a Bacillus megaterium isolate known to control sheath blight disease was subjected to spray-drying in the presence of skim milk powder and PVP as the main carriers. The spray-dried powder was evaluated for its physical characteristics, and the viability and efficacy of $B$. megaterium to control sheath blight disease in a pot experiment. 


\section{Materials and Methods}

\section{Materials}

Skim milk was obtained from Merck (Darmstadt, Germany) and polyvinyl pyrrolidone k-90 (PVP, k-90) was supplied by Fluka (Buchs, Switzerland). Iprodione (Rovral ${ }^{\mathbb{R}}$ Fungicide) was from Bayer Crop Sciences (Victoria, Australia). Plate count agar (PCA) (DifcoÒ) was from Becton Dickinson and Company (New Jersey, USA). Potato dextrose agar (PDA) was prepared using $200 \mathrm{~g}$ of potato, $20 \mathrm{~g}$ of dextrose, $17 \mathrm{~g}$ of agar and 1 litre of distilled water. B. megaterium and $R$. solani were obtained from the Laboratory of Biological Control Agent Formulation, Prince of Songkla University, Thailand (Kanjanamaneesathian et al. 1998).

\section{Preparation of bacterial endospore suspension}

A suspension of $B$. megaterium endospores was prepared as described by Chumthong et al. (2008). The bacterium was cultured in potato dextrose broth (PDB) at $30-35{ }^{\circ} \mathrm{C}$, stirring at $200 \mathrm{rpm}$ for 4 days, and bacterial cells at the stationary growth stage were separated by centrifugation at 3,000 rpm for $10 \mathrm{~min}$. The isolated cells were washed 3 times and re-suspended in sterile distilled water $(1: 2 \mathrm{v} / \mathrm{v})$. The cells were incubated in a water bath at $80^{\circ} \mathrm{C}$ for $20 \mathrm{~min}$ to kill the vegetative cells. The endospores of $B$. megaterium were enumerated on plate count agar (PCA) using a drop on plate technique (Zuberer 1994). The plates were incubated at $37^{\circ} \mathrm{C}$ for 1 day after which colony-forming units (cfu) were counted. The viable bacterial concentrations $(\mathrm{cfu} / \mathrm{ml})$ recorded were the average of four replicate plates from each dilution.

\section{Preparation of powder formulations using spray-drying}

Three bacterial formulations (BM100, BM120, BM140) were prepared by spray-drying with inlet temperatures of either 100,120 or $140{ }^{\circ} \mathrm{C}$, using a spray dryer B-191 (Büchi; Flawil, Switzerland). The formulation was composed of $20 \% \mathrm{w} / \mathrm{v}$ of skim milk powder $(50 \mathrm{ml}), 1.25 \% \mathrm{w} / \mathrm{v}$ of PVP K-90 $(30 \mathrm{ml})$ and $20 \mathrm{ml}$ of a suspension of bacterial endospores. The outlet temperature for all formulations was in the range $52.0-71.5^{\circ} \mathrm{C}$. The feed spray rate was varied from 3.1-3.2 $\mathrm{ml} / \mathrm{min}$, depending on the level of the inlet air temperature. The powder was stored in sterile plastic tubes at room temperature. B. megaterium in the spray-dried powder was enumerated at 1 month intervals for 12 months.

Viable bacterial counts in the formulations were determined using the drop on plate method (Zuberer 1994). A $0.1 \%$ suspension of each bacterial formulation was prepared in sterile distilled water $(n=3)$. The viable bacteria were cultured on PCA at $37{ }^{\circ} \mathrm{C}$ for 18 $24 \mathrm{~h}$ after which the cfu was counted. The value (cfu/g) of viable bacteria was the average of six drops per dilution. 


\section{Testing the inhibition of $\mathrm{R}$. solani mycelial growth on agar}

The inhibition of mycelial growth of $R$. solani by $B$. megaterium powder formulations was evaluated as described by Wiwattanapatapee et al. (2007) after production and during storage at room temperature $\left(26-30^{\circ} \mathrm{C}\right)$ in plastic containers for 12 months. One g of the bacterial granules was dissolved in $99 \mathrm{ml}$ of sterile distilled water. One $\mathrm{ml}$ of this solution was sampled and mixed with melted potato dextrose agar (PDA) at 1:10 (v/v) in Petri dishes (9.0 cm diameter). An agar block of growing $R$. solani was cultured on PDA that had been incorporated with a suspension of the bacterial formulation to test for the inhibition of $R$. solani mycelial growth. Each treatment consisted of six replications. Cultures of $R$. solani on PDA incorporated with sterile water were used as a control. Mycelial inhibition of $R$. solani was assessed as \% mycelial inhibition $36 \mathrm{~h}$ after culturing $R$. solani [Equation (1)] (Gamliel et al. 1989).

$$
\% \text { mycelial inhibition }=100-\left[\left(\mathrm{r}^{2} / \mathrm{R}^{2}\right) \times 100\right]
$$

In equation (1), $\mathrm{r}$ is the colony radius of $R$. solani on PDA incorporated with $1 \%$ solution of bacterial formulation and $\mathrm{R}$ is colony radius of $R$. solani on PDA incorporated with sterile water.

\section{Efficacy of the bacterial powder in controlling sheath blight disease in the greenhouse}

Soil for growing rice in the greenhouse was prepared as described by Kanjanamaneesathian et al. (1998). Soil samples were loaded into plastic pots $(21 \mathrm{~cm}$ in diameter and 18 $\mathrm{cm}$ in height) and the pot was filled with tap water until the soil was soaked. The water level was maintained above the soil level. After $72 \mathrm{~h}$, the soil was agitated manually to break up aggregates and excess water was drained. Soil level in the plastic pots was adjusted to a height of $14.5 \mathrm{~cm}$ and a $3.5 \mathrm{~cm}$ depth of water was retained in each plastic pot. There were seven treatments, and each treatment consisted of six pot replications (with 3 plants/replication). Rice plants (cv. RD-23) inoculated only with $R$. solani were used as

Table 1. Treatments tested for the control of rice sheath blight disease under greenhouse conditions

\begin{tabular}{|c|c|}
\hline Treatment & Description \\
\hline Blank & $\begin{array}{l}\text { Sprayed with } 0.1 \% \mathrm{w} / \mathrm{v} \text { aqueous blank formulation without bacterial endospores } \\
(100 \mathrm{ml} / \mathrm{pot})\end{array}$ \\
\hline BM120-b & $\begin{array}{l}\text { Sprayed with a } 0.1 \% \mathrm{w} / \mathrm{v} \text { aqueous formulation } 1 \text { day before pathogen inoculation } \\
(100 \mathrm{ml} / \mathrm{pot})\left(4.7 \times 10^{10} \mathrm{cfu} / \mathrm{pot}\right)\end{array}$ \\
\hline BM120-b,a & $\begin{array}{l}\text { Sprayed with a } 0.1 \% \mathrm{w} / \mathrm{v} \text { aqueous formulation } 1 \text { day before pathogen inoculation } \\
\text { and } 1,7 \text { and } 15 \text { days after pathogen inoculation }(100 \mathrm{ml} / \mathrm{pot})\left(4.7 \times 10^{10} \mathrm{cfu} / \mathrm{pot}\right)\end{array}$ \\
\hline BM120-a & $\begin{array}{l}\text { Sprayed with a } 0.1 \% \mathrm{w} / \mathrm{v} \text { aqueous formulation } 1,7 \text { and } 15 \text { day after pathogen } \\
\text { inoculation }(100 \mathrm{ml} / \mathrm{pot})\left(4.7 \times 10^{10} \mathrm{cfu} / \mathrm{pot}\right)\end{array}$ \\
\hline Fresh cells & $\begin{array}{l}\text { Sprayed with fresh cells (Unformulated spore suspension) } 1 \text { day after pathogen } \\
\text { inoculation }(100 \mathrm{ml} / \mathrm{pot})\left(5.6 \times 10^{10} \mathrm{cfu} / \mathrm{pot}\right)\end{array}$ \\
\hline Chemical fungicide & Sprayed with $0.15 \%$ Iprodione liquid 1 day after pathogen inoculation $(100 \mathrm{ml} / \mathrm{pot})$ \\
\hline Control & Rice plants inoculated only with $R$. solani (No treatment) \\
\hline
\end{tabular}


a control treatment. The experiment was arranged in a Completely Randomized Design (CRD).Treatment details for the greenhouse experiment are shown in Table 1.

Assessment of the efficacy of the formulations to control sheath blight was conducted 90 days after transplanting the rice seedling to the pot. Before disease assessment, roots of the rice plants were washed to eliminate excessive soil. These roots were later cut and discarded and the aboveground portions of the rice plants were used for sheath blight disease assessment. Disease was assessed by measuring the lesion length and the average lesion length/tiller was calculated $(n=6)$. The percentage relative lesion height $(\% \mathrm{RLH})$ was calculated [Equation (2)] as described by Anh et al. (1986) $(\mathrm{n}=6)$.

$$
\% \mathrm{RLH}=\mathrm{Li} / \mathrm{Lt} \times 100
$$

In equation (1), $\mathrm{Li}$ is the length of the lesion and $\mathrm{Lt}$ is the length of the rice tillers.

\section{Statistical analysis}

Data were subjected to one-way analysis of variance and was carried out on the mean values of the lesion length $(n=6)$ and the mean values of the percentage of tillers $(n=6)$ showing sheath blight symptoms. Data were compared with Duncan's Multiple Range Test (DMRT) at $P<0.01$ or $P<0.05$.

\section{Results}

All bacterial powder formulations (at $0.1 \% \mathrm{w} / \mathrm{v}$ ) were completely dissolved in water within 3-7 min following stirring at $250 \mathrm{rpm}$ at room temperature. The percentage yield was highest, at $33.9 \pm 0.0 \%(\mathrm{n}=3)$, when the formulation containing the bacterial suspension was subject to the inlet air temperature at $120^{\circ} \mathrm{C}$ (Table 2).

\section{Dissolution time}

0.1 percent of each powder formulation was dissolved in distilled water, at room temperature $\left(26-30^{\circ} \mathrm{C}\right)$. The powders were stirred at $250 \mathrm{rpm}$ until they were completely

Table 2. Process parameters adjusted for spray-drying and the resulting of bacterial formulations

\begin{tabular}{|c|c|c|c|c|c|c|}
\hline \multirow{2}{*}{ Formulation } & \multicolumn{2}{|c|}{ Drying temperature $\left({ }^{\circ} \mathrm{C}\right)^{*}$} & Suspension feed & Moisture content \\
& Air inlet & Air outlet & $\begin{array}{c}\text { Dissolution time } \\
(\mathrm{min})\end{array}$ & $\begin{array}{c}\text { Yield } \\
(\%)\end{array}$ \\
\hline BM100 & 100 & $52.0 \pm 2.2^{\mathrm{c}}$ & $3.1 \pm 0.0^{\mathrm{b}}$ & $0.23 \pm 0.03^{\mathrm{a}}$ & $6.7 \pm 0.3^{\mathrm{a}}$ & $28.3 \pm 0.0^{\mathrm{c}}$ \\
\hline BM120 & 120 & $58.5 \pm 2.7^{\mathrm{b}}$ & $3.2 \pm 0.0^{\mathrm{a}}$ & $0.18 \pm 0.02^{\mathrm{ab}}$ & $3.7 \pm 0.5^{\mathrm{b}}$ & $33.9 \pm 0.0^{\mathrm{a}}$ \\
\hline BM140 & 140 & $71.5 \pm 0.6^{\mathrm{a}}$ & $3.2 \pm 0.0^{\mathrm{a}}$ & $0.15 \pm 0.01^{\mathrm{b}}$ & $3.5 \pm 0.1^{\mathrm{b}}$ & $29.9 \pm 0.0^{\mathrm{b}}$ \\
\hline C.V. $(\%)$ & & $3.3^{* *}$ & $0.9^{* *}$ & $9.6^{* *}$ & $6.9^{* *}$ & $0.4^{* *}$ \\
\hline
\end{tabular}

*Spray-nozzle diameter, $0.7 \mathrm{~mm}$; aspirator, 50\%; pump, $10 \%$; flow of compressed air, $700 \mathrm{~N}^{1} \mathrm{~h}^{-1}$.

**Means followed by the same letter are not significantly different by Duncan's Multiple Range Test at $P<0.01$.

*** Moisture content: The moisture content was determined in a hot-air oven at $60{ }^{\circ} \mathrm{C}$, until constant weight was reached. Three replicates were performed for each formulation. 
dissolved. Dissolution time of the powder was recorded and three replicates were performed for each formulation.

\section{Yield}

Percentage yield was calculated [Equation (3)]. Three replicates were performed for each formulation. Formulations with a yield of more than $30 \%$ were chosen for further studies.

$$
\% \text { Yield }=(\text { outlet weight } / \text { inlet weight }) \times 100
$$

\section{Enumeration of viable bacteria in the spray-dried powder formulations}

The number of viable bacteria in the BM100, BM120 and BM140 formulations was $3.6 \pm 0.0 \times 10^{12}, 3.5 \pm 0.1 \times 10^{11}$ and $2.9 \pm 0.2 \times 10^{11} \mathrm{cfu} / \mathrm{g}(\mathrm{n}=3)$, respectively. The numbers of bacteria remained high after the formulation was produced and stored at room temperature for 12 months (Table 3 ).

Table 3. The number of viable bacterium in the formulations at inlet temperatures of 100,120 and $140{ }^{\circ} \mathrm{C}$ after 12 months storage at room temperature

\begin{tabular}{|c|c|c|c|c|c|}
\hline \multirow{2}{*}{ Formulation } & \multicolumn{5}{|c|}{$\mathrm{cfu} / \mathrm{g}^{*}$} \\
\cline { 2 - 6 } & 0 & 3 & 6 & 9 & 12 \\
\hline BM100 & $3.6 \pm 0.0 \times 10^{12}$ & $2.7 \pm 0.1 \times 10^{11}$ & $2.0 \pm 0.2 \times 10^{10}$ & $3.0 \pm 0.1 \times 10^{10}$ & $1.0 \pm 0.1 \times 10^{10}$ \\
\hline BM120 & $3.5 \pm 0.1 \times 10^{11}$ & $5.1 \pm 0.1 \times 10^{10}$ & $4.7 \pm 0.1 \times 10^{10}$ & $3.7 \pm 0.0 \times 10^{10}$ & $2.2 \pm 0.1 \times 10^{10}$ \\
\hline BM140 & $2.9 \pm 0.2 \times 10^{11}$ & $5.7 \pm 0.2 \times 10^{10}$ & $2.6 \pm 0.2 \times 10^{10}$ & $2.6 \pm 0.1 \times 10^{10}$ & $1.7 \pm 0.1 \times 10^{10}$ \\
\hline
\end{tabular}

$* \mathrm{n}=3$.

Table 4. The effectiveness of bacterial formulations to inhibit the mycelial growth of $R$. solani after 12 months storage at room temperature

\begin{tabular}{|c|c|c|c|c|c|}
\hline \multirow{2}{*}{ Formulation } & \multicolumn{5}{|c|}{ Mycelial inhibition $(\%, \mathrm{n}=3)$} \\
\cline { 2 - 6 } & 0 & 3 & 6 & 9 & $12^{*}$ \\
\hline BM100 & $99.7 \pm 0.3^{\mathrm{a}}$ & $99.5 \pm 1.1^{\mathrm{a}}$ & $99.2 \pm 1.3^{\mathrm{a}}$ & $98.7 \pm 1.5^{\mathrm{a}}$ & $98.1 \pm 0.3^{\mathrm{a}}$ \\
\hline BM120 & $99.5 \pm 0.1^{\mathrm{a}}$ & $99.3 \pm 0.2^{\mathrm{a}}$ & $99.1 \pm 0.6^{\mathrm{a}}$ & $98.3 \pm 0.6^{\mathrm{a}}$ & $98.5 \pm 0.1^{\mathrm{a}}$ \\
\hline BM140 & $99.4 \pm 0.5^{\mathrm{a}}$ & $99.2 \pm 0.3^{\mathrm{a}}$ & $98.8 \pm 1.2^{\mathrm{a}}$ & $98.8 \pm 0.7^{\mathrm{a}}$ & $98.6 \pm 0.2^{\mathrm{a}}$ \\
\hline Control & $00.0 \pm 0.0^{\mathrm{b}}$ & $00.0 \pm 0.0^{\mathrm{b}}$ & $00.0 \pm 0.0^{\mathrm{b}}$ & $00.0 \pm 0.0^{\mathrm{b}}$ & $00.0 \pm 0.0^{\mathrm{b}}$ \\
\hline C.V.(\%) & $1.4^{* *}$ & $0.3^{* *}$ & $1.8^{* *}$ & $0.8^{* *}$ & $0.4^{* *}$ \\
\hline
\end{tabular}

*Assessment of the \% mycelial inhibition 0, 3, 6, 9 and 12 months after storage at room temperature, respectively.

**The mean values followed by the same letter were not significantly different by the Duncan's Multiple Range Test at $p<0.01$. 
Although the lower outlet air temperature (100) during the spray drying resulted in a higher bacterial viability than at a higher temperature, the effects of its higher residual moisture content may have caused some loss of bacterial viability (Table 3 ) and the formulation was denatured over the 12 month period (such as coagulation and colour change, data not shown) during storage at room temperature.

\section{Inhibition of $R$. solani mycelial growth}

The bacterial formulations had high ability to inhibit the mycelial growth of $R$. solani on plates after preparation (more than $90 \%(n=3)$ mycelial inhibitions), even though the tests were carried out after 12 months of storage at room temperature (Table 4). The differences in activity against mycelium growth of $R$. solani of each formulation was not significant, but significantly different from control at $P<0.01$ (Table 4).

\section{Greenhouse test}

In the greenhouse tests, spraying an aqueous solution $(0.1 \% \mathrm{w} / \mathrm{v})$ of the $120^{\circ} \mathrm{C}$ powder formulation containing endospores of $B$. megaterium 1,7 and 15 days after inoculation with the pathogen $\left(4.7 \times 10^{10} \mathrm{cfu} / \mathrm{pot}\right)$ was effective in suppressing sheath blight disease (Table 5). A similar aqueous solution of the control formulation (without $B$. megaterium) did not control sheath blight in the pot test. However, the chemical fungicide $(0.15 \%$ Iprodione) was better than the powder formulation when the numbers of lesion/tiller, lesion length and \% severity were assessed (Table 5).

Table 5. Efficacy of bacterial formulation in inhibited sheath blight disease in pot test

\begin{tabular}{|l|c|c|}
\hline \multicolumn{1}{|c|}{ Treatment } & $\begin{array}{c}\text { Lesion length (cm)/tiller } \\
(\mathrm{n}=6)\end{array}$ & $\begin{array}{c}\text { Severity (\%RLH) } \\
(\mathrm{n}=6)\end{array}$ \\
\hline 1. Blank & $34.4 \pm 1.9^{\mathrm{a}}$ & $66.6 \pm 1.4^{\mathrm{a}}$ \\
\hline 2. BM120-b & $17.0 \pm 2.7^{\mathrm{bc}}$ & $39.3 \pm 6.2^{\mathrm{b}}$ \\
\hline 3. BM120-b,a & $15.6 \pm 1.9^{\mathrm{c}}$ & $28.3 \pm 3.8^{\mathrm{c}}$ \\
\hline 4. BM120-a & $19.3 \pm 2.0^{\mathrm{b}}$ & $34.0 \pm 2.9^{\mathrm{bc}}$ \\
\hline 5. Fresh cell & $17.6 \pm 2.9^{\mathrm{bc}}$ & $34.0 \pm 8.7^{\mathrm{bc}}$ \\
\hline 6. Chemical fungicide & $8.2 \pm 1.4^{\mathrm{d}}$ & $19.6 \pm 2.1^{\mathrm{d}}$ \\
\hline 7. Control (only R. solani) & $33.0 \pm 1.8^{\mathrm{a}}$ & $63.1 \pm 3.5^{\mathrm{a}}$ \\
\hline C.V. $(\%)$ & $10.5^{*}$ & $11.6^{*}$ \\
\hline
\end{tabular}

*Means followed by the same letter are not significantly different by Duncan's Multiple Range Test at $P<0.05$. 


\section{Discussion}

Although the spray-dried product of Bacillus sp., especially B. subtilis (Yánez-Mendizábal et al. 2012), has been devised and tested to control insect pests and plant disease, a spraydried product of $B$. megaterium has not previously been formulated and tested for the control of rice sheath blight disease.

In the present work we have reported the protocol and appropriate ingredients used for producing a stable spray-dried powder of B. megaterium. The spray-dried product with bacterium produced at the regime of inlet air temperature of $120{ }^{\circ} \mathrm{C}$ gave highest yield and possessed other beneficial characteristics, such as low moisture content and short dissolution time (Table 2).

Our spray-dried formulation showed satisfactory physical characteristics (Table 2) and verified that skim milk powder and PVP were appropriate carriers that could be used for spray drying. Skim milk powder has been reported to possess both thermal conductivity and diffusivity, and attributing it to having beneficial characteristic in protecting bacterial cells against any abrupt temperature change. Lian et al. (2002) have also attributed the high survival of bifidobacteria to $10 \% \mathrm{w} / \mathrm{v}$ skim milk powder. A stable and effective formulation of $B$. subtilis CPA-8 was obtained by spray-drying in the presence of $10 \%$ skimmed milk powder and PVP as carriers and protecting agents (Yánez-Mendizábal et al. 2012).

The air temperature at the inlet and outlet of the spray drier affected the viability of bacteria in the spray dried powders (Johnson and Etzel 1993). The end product of the spray-dried formulation subjected to the inlet air temperature at $100{ }^{\circ} \mathrm{C}$ contained the highest number of bacteria at $3.6 \pm 0.0 \times 10^{12} \mathrm{cfu} / \mathrm{g}$ (Table 3). As a consequence, there was a trade-off between the physical characteristics (moisture content and dissolution time) and the numbers of bacteria. The spray-dried product, providing the highest yield and possessed other beneficial characteristics, such as a low moisture content and a short dissolution time (Table 2), had a relatively lower number of viable bacteria $3.5 \times 10^{11}$ (Table 3).

Boza et al. (2004) reported that a reduced outlet air temperature contributed to the increase in viability of Beijerinckia sp. To and Etzel (1997b) also confirmed that a high survival of Brevibacterium linens could be attained when the outlet air temperature was maintained below $57^{\circ} \mathrm{C}$. The drying temperature cannot be infinitely decreased as the moisture content of the spray-dried product may increase significantly.

In the present study, when the spray-dried product with bacterium was produced with an inlet air temperature at $140{ }^{\circ} \mathrm{C}$, an outlet air temperature below $72{ }^{\circ} \mathrm{C}$ was observed (Table 2). At this temperature regime, the end product still possessed a high number of viable bacteria (Table 3 ). This indicated that the chemical agents and proportion of the ingredients used in conjunction with the inlet and outlet air temperatures were suitable to maintain bacterial viability and their ability to inhibit mycelial growth of $R$. solani (Table 4).

The effect of high residual moisture content in the product may also contribute to both the degradation of the product and the decrease of bacterial viability. The physical proper- 
ties of BM100, which had the comparatively higher moisture content $(0.23 \%)$, exhibited different characteristics. The product formed aggregates and was discoloured. The bacterial viability in BM100 formulation decreased faster than that of BM120 and BM140 formulations during the 12-months storage at room temperature (Table 3). However, the aggregation and discoloration of a spray-dried product of BM100 with reduced bacterial number (Table 3) did not affect its capacity to inhibit mycelial growth of $R$. solani (Table 4).

In the greenhouse, a chemical fungicide was more effective than any of the formulations in suppressing sheath blight severity when average lesion length/tiller and relative lesion height (RLH) were evaluated (Table 5). The fact that spray-dried products were as effective as the fresh cells of the bacterium in suppressing sheath blight disease confirmed that the protocol used for devising the spray-dried product in this study had no effect on both the viability of the bacterium and the capability of the bacterium to suppress disease development.

\section{Acknowledgement}

We would like to thank Dr. Brian Hodgson for assistance with the English.

\section{References}

Abadias, M., Benabarre, A., Teixido, N., Usall, J., Vinas, I. 2001. Effect of freeze-drying and protectants on viability of the biocontrol yeast Candida sake. Int. J. of Food Microbiol. 65:173-182.

Ananta, E., Volkert, M., Knorr, D. 2005. Cellular injuries and storage stability of spray-dried Lactobacillus rhamnosus GG. Int. Dairy J. 15:399-409.

Anh, S.W., de La Pena, R., Candole, B.L., Mew, T.W. 1986. A new scale for rice sheath blight disease assessment. International Rice Research Institute. Manila, Philippines. pp. 11, 17.

Boza, Y., Barbin, D., Scamparini, A.R.P. 2004. Effect of spray-drying on the quality of encapsulated cells of Beijerinckia sp. Process Biochem. 39:1275-1284.

Burges, H.D. 1998. Formulation of mycoinsecticides. In: Burges, H.D. (ed.), Formulation of Microbial Biopesticides: Beneficial microorganism, Nematodes and Seed treatments, Kluwer Academic Publishers. Dordrecht, The Netherlands. pp. 131-187.

Bühler, V. 2001. Kollidon: Polyvinyl Pyrrolidone for the Pharmaceutical Industry. 6th Ed. BASF, Pharma Ingredients. Ludwigshafen, Germany. pp. 139-157.

Chumthong, A., Kanjanamaneesathian, M., Pengnoo, A., Wiwattanapatapee, R. 2008. Water-soluble granules containing Bacillus megaterium for biological control of rice sheath blight: Formulation, bacterial viability and efficacy testing. World J. of Microbiol. and Biotechnol. 24:2499-2507.

Conrad, P.B., Miller, D.P., Cielenski, P.R., de Pablo, J.J. 2000. Stabilization and preservation of Lactobacillus acidophilus in saccharide matrices. Crybiology 41:17-24.

Desmond, C., Stanton, C., Fitzgerald, G.F., Collins, K., Ross, R.P. 2001. Environmental adaptation of probiotic lactobacilli towards improvement of performance during spray drying. Int. Dairy J. 11:801-808.

Gamliel, A., Katan, J., Cohen, E. 1989. Toxicity of chloronitrobenzenes to Fusarium oxysporum and Rhizoctonia solani as related to their structure. Phytoparasitica 17:101-106.

Gnanamanickam, S.S., Candole, B.L., Mew, T.W. 1992. Influence of soil factors and cultural practice on biological control of sheath blight of rice with antagonistic bacteria. Plant and Soil 144:67-75.

Horaczek, A., Viernstein, H. 2004. Comparison of three commonly used drying technologies with respect to activity and longevity of aerial conidia of Beauveria brongniartii and Metarhizium anisopliae. Biol. Control 31:65-71. 
Johnson, J.A.C., Etzel, M.R. 1993. Inactivation of lactic acid bacteria during spray-drying. Aiche Symposium 89:89-107.

Johnson, J.A.C., Etzel, M.R. 1995. Properties of Lactobacillus helveticus CNRZ-32 attenuated by spray-drying, freeze-drying, or freezing. J. Dairy Sci. 78:761-768.

Kanjanamaneesathian, M., Chumthong, A., Pengnoo, A., Wiwattanapatapee, R. 2009. Bacillus megaterium suppresses major Thailand rice diseases. Asian J. of Food and Agro-Industry S:154-159.

Kanjanamaneesathian, M., Kusonwiriyawong, C., Pengnoo, A., Nilratana, L. 1998. Screening of potential bacterial antagonists for control of sheath blight in rice and development of suitable bacterial formulations for effective application. Australasian Plant Pathol. 27:198-206.

Kumar, K.V.K., Yellareddygari, S.K.R., Reddy, M.S., Kloepper, J.W., Lawrence, K.S., Miller, M., Sudini, H., Surendranatha, Reddy, E.C., Zhou, X.G., Groth, D.E. 2013. Ultrastructural studies on the interaction between Bacillus subtilis MBI 600 (Integral) and the rice sheath blight pathogen, Rhizoctonia solani. African J. of Microbiol. Res. 7:2078-2086.

Lian, W.C., Hsiao, H.C., Chou, C.C. 2002. Survival of bifidobacteria after spray-drying. J. Food Microbiol. 74:79-86.

Mosquera-Espinosa, A.T., Bayman, P., Prado, G.A., Gómez-Carabalí, A., Otero, J.T. 2013. The double life of Ceratobasidium: orchid mycorrhizal fungi and their potential for biocontrol of Rhizoctonia solani sheath blight of rice. Mycologia 105:141-150.

Naeimi, S., Okhovvat, S.M., Javan-Nikkhah, M., Vágvölgyi, C., Khosravi, V., Kredics, L. 2010. Biological control of Rhizoctonia solani AG1-1A, the causal agent of rice sheath blight with Trichoderma strains. Phytopathologia Mediterranea 49:287-300.

Savary, S., Willocquet, L., Elazegui, F.A., Castilla, N.P., Teng, P.S. 2000. Rice pest constraints in tropical Asia: quantification of yield losses due to rice pests in a range of production situations. Plant Dis. 84:357-369

Selmer-Olsen, E., Sorhaug, T., Birkeland, S.E., Pehrson, R. 1999. Survival of Lactobacillus helveticus entrapped in Ca-alginate in relation to water content, storage and rehydration. J. of Industrial Microbiol. Biotechnol. 23:79-85.

To, B.C.S., Etzel, M.R. 1997a. Spray drying, freeze drying, or freezing of three different lactic acid bacteria species. J. Food Sci. 62:576-578.

To, B.C.S., Etzel, M.R. 1997b. Survival of Brevibacterium linens ATCC 9174 after spray drying, freeze drying, or freezing. J. Food Sci. 62:167-170.

Wiwattanapatapee, R., Chumthong, A., Pengnoo, A., Kanjanamaneesathian, M. 2007. Effervescent fast-disintegrating bacterial formulation for biological control of rice sheath blight. J. of Controlled Release 119:229235.

Yánez-Mendizábal, V., Viñas, I., Usall, J., Torres, R., Solsona, C., Abadias, M., Teixidó, N. 2012. Formulation development of the biocontrol agent Bacillus subtilis strain CPA-8 by spray-drying. J. Appl. Microbiol. 112:954-965.

Zamora, L.M., Carretero, C., Pares, D. 2006. Comparative survival rates of lactic acid bacteria isolated from blood, following spray-drying and freeze-drying. Food Sci. and Technol. Int. 12:77-84.

Zuberer, D.A. 1994. Recovery and enumeration of viable bacteria. In: Weaver, R.W., Angle, S., Bottomley, P., Bezdicek, D., Smith, S., Tabatabai, A., Wollum, A. (eds), Methods of Soil Analysis: Part 2, Microbiological and Biochemical Properties, Number 5. In Soil Science Society of America Book Series. Soil Science Soc. of America Inc. Wisconsin, USA. pp. 119-143. 